\title{
CLAYEY RAW MATERIALS FROM DOBROGEA, SOUTHERN ROMANIA, USING IN TRADITIONAL CERAMICS
}

Marica S., Ciornei N., Cetean V.

Raw Materials Laboratory, PROCEMA GEOLOGI, 136 Calea Grivitei, S1, 010707 Bucharest georock@rdslink.ro

\section{ABSTRACT}

This paper presents the results of geological and technological research on clayey and loessoid raw materials from the continental platform of the Black Sea. The loessoid clays undergo an open cut mining under very good technical-economic conditions and are processed in a neighbouring factory. The clay deposits from the Cobadin plateau belong to the category of silt grains with the particle sizes between 0.01 and $0.03 \mathrm{~mm}$. The physic-ceramic determinations proved that the clays from the Cobadin Plateau have a good shapability as raw materials. The clay preparation and working process includes: maceration in the quarry, preparation of the material by batching and mixing, shaping, compacting, finishing, hardening. The products are dried in the Kowo type natural dryers of the factory and firing takes place in a Hoffman kiln at a temperature of $950-1000^{\circ} \mathrm{C}$.

\section{INTRODUCTION}

This paper presents the results of geological and technological research on clayey raw materials from South Dobrogea (Ciornei et al., 2002), namely from the continental platform of the Black Sea. The deposit under research is situated on a raised area of the Cobadin Plateau, a morphological unit about $38 \mathrm{~km}$ west of the Constantza city (Fig. 1).

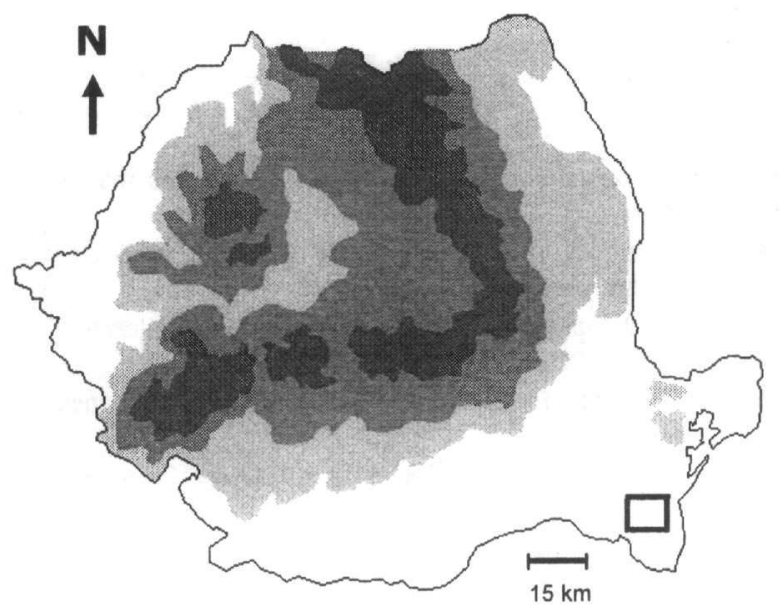

Figure 1. Localization of Cobadin clayey deposit

Exploitation of the ordinary and loessoid clay deposits from Cobadin started about 3 decades ago; at present there is a "pit quarry" opened up in the immediate vicinity of the factory, with very good exploitation conditions (Fig. 2). The initial reserves were extended adjacent to the central perimeter and the homogeneity of the raw material to a great ex- 
tent outside from the centre of the quarry assures that it may operate over several future decades.

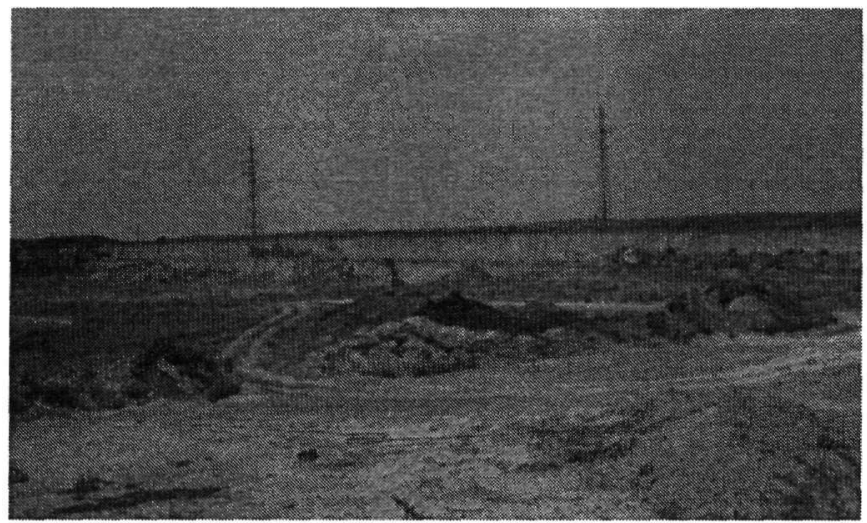

Figure 2. General view of the Cobadin quarry

Southern Dobrogea represents a territory apart from other Romanian territories due to its special structure (Mutihac, 1990). This is a rather raised area of the Moessic plateau and has a folded bed consisting of crystalline schist and green schist. The sedimentary cover consisting of slightly folded formations is set over the schist.

From a morphological point of view, the region of Southern Dobrogea has the highest altitude on east west structural line forming a plateau descending to the Danube in the west and to the Black Sea in the east. The central area of this plateau is called the Cobadin plateau whose centre is more raised because of the curving of the Sarmatian formations occurring here.

The Quaternary formations, where the usable ceramic raw materials are included, consist of an alternation of loessoid formations and of fossil clayey soil, with maximum thickness exceeding $40 \mathrm{~m}$ and melding an old form of relief that indicates their aeolian origin, a characteristic specific to this high steppe region situated west from the continental plateau of the Black Sea.

\section{MATERIALS AND METHODS}

The present paper represents the results of geological and ceramic researches (Marica, 1993; 2001) on clayey raw materials from the southern Dobrogea, Cobadin Plateau. The clayey and loessoid deposits from Cobadin are studied by petrographical, mineralogical (XR analyses), oxydic and physical-ceramic investigations. Final documentation contained an evaluation of quantity of the resources, feasibility studies and experiments on products obtained from samples taken from drilling core and from the quarry shafts.

\section{GEOLOGICAL SETTING}

The loess and loessoid clay profiles in Dobrogea represented a favourite target of the researches as far as fossil soils and paleosoils, the periglacial phenomena in loesses, the determinations of the absolute ages and the glacial periods are concerned.

From this point of view, the geological profile opened in the Cobadin quarry is significant for the stratigraphical interpretation of the area. From the drillings and researches carried out it was found that the loessoid succession is fairly evident both horizontally and vertically and the presence of some less developed fossil soils at upper part as intercalations between the useful layers is evident. These fossil soils are attributed as far as age is concerned to certain intervals of the Würm sublevel (that last glaciation) of the higher 
Pleistocene when they were well developed and they have a grey and reddish-brown colour (Fig. 3).

Lithological succession is: 1 . loessoid grey-yellow clay; 2 . grey, sandy clay; 3 . reddish - grey compact clay; 4. compact loessoid clay with calcareous fragments; 5 . reddish brown clay; 6 . brown -reddish clay with calcareous fragments; 8 . loessoid white clay; 9 . clayey limestone.

The loessoid clays from Cobadin have a generally yellow-grey colour, are fine, macroporous and often present canals, pores and whitish stains. The loess is of a wind nature, has a semi-mobile deposit character and was laid down over the fossil soils during a climate change period, a fact found out by the presence of some artic fauna or extreme steppe levels. Some sterile limy concretions were found at the base of these deposits.

\section{QUALITATIVE CHARACTERISATION}

\subsection{Lithological - mineralogical characteristics}

From a macroscopic point of view, the clays have a massive appearance, the tendency of detachment to vertical planes, colours from yellowish to whitish-yellowish up to grey-yellowish and a high porosity. The grading determinations on the loessoid clay pointed out two aspects: the coarse fraction (sand) larger than $0.06 \mathrm{~mm}$ has low representation (6\% in fossil soils) and dominance of the fraction with particles passing through the $0.063 \mathrm{~mm}$ sieve (over $90 \%$ ).

According the Holmes and Hopkins grading scales, the clayey raw materials are included in the category of silts (loesses) or aleurites, passing on to fine sands which therefore have particle dimensions between $0.01 \mathrm{~mm}$ and $0.03 \mathrm{~mm}$.

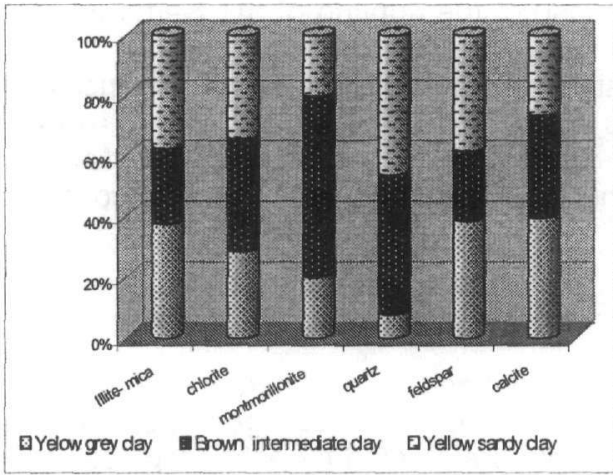

Figure 3 Mineralogical composition of clay

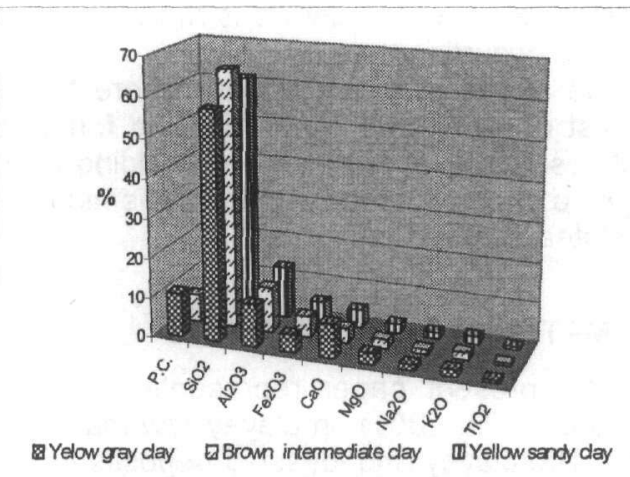

Figure 4 Oxidic composition of studied clay

\subsection{Chemical composition}

The chemical analysis (Fig. 4) performed on samples from each horizon demonstrated the similitude of the alues in all three samples, starting from the vegetal soil to the reddish clay with concretions, which demonstrates the continuity of sedimentation in the area during Pleistocene. The high $\mathrm{SiO}_{2}$ values point out to the siliceous appearance of the clay, therefore to the terrigene, continental stress of the emerged periods. The $\mathrm{CaO}$ values increase with depth and are distinctly superior in paleosoils fact that may be explained by the presence of the limy fragments.

The chemical composition indicates the possibility of many applications of these clays in the fields of roof tiles, bricks, terra cota wall tiles and pottery. 


\subsection{Physico-ceramic characteristics}

They were determined on samples selected from the drillings. The pastes prepared with material from all the drilled horizons. The determinations conducted prior to firing on these prepared pastes led to obtain some average values with specific conclusions ( $\mathrm{Ta}$ ble 1).

Table 1. Characteristics of samples before firing

\begin{tabular}{llll}
\hline Characteristics & Value & U.M & Remarks \\
\hline $\begin{array}{l}\text { Shapability moisture } \\
\text { ity moisture }\end{array}$ & 23.2 & $\%$ & Good shapabil- \\
$\begin{array}{l}\text { Water absorption } \\
\begin{array}{l}\text { Pfefferkorn plasticity } \\
\text { ticity }\end{array}\end{array}$ & 29.82 & $\%$ & $\begin{array}{l}\text { High absorption } \\
\begin{array}{l}\text { Binding capacity } \\
\text { pacity }\end{array}\end{array}$ \\
$\begin{array}{l}\text { Drying shrinkage } \\
\text { age }\end{array}$ & 138.52 & $\mathrm{I} . \mathrm{P}$ & $\mathrm{S}$ Significant plas- \\
\hline
\end{tabular}

The determinations after firing were made on the same sample bodies fired at temperatures of $900^{\circ} \mathrm{C}$ and $1000^{\circ} \mathrm{C}$ in the electric furnace. The products had adequate total shrinkage after firing (8.64-9.04\%) and also good compression strength, between $202.42 \mathrm{daN} / \mathrm{sqcm}$ and $363.4 \mathrm{daN} / \mathrm{sqcm}$.

\section{EXPLOITATION CONDITIONS}

The quarry (Fig. 2) has a circumference with a 1.7 diameter $\mathrm{km}$ open face of about $150 \mathrm{~m}$ in length and $50 \mathrm{~m}$ in width at two working benches with a height of about $5 \mathrm{~m}$ each. Clay extraction is made in the natural mixture along the entire length of the face up to the platform floor. Storage is made in the maceration storage area which is surrounded by drain ditches.

On a dry weather, the clay is wetted before being introduced in the manufacture by making holes in the clay at one meter intervals about, moistering being carried on until reaching a uniform value, required by shaping which is about $25 \%$. Mixing of the various types of clay is made in the quarry and the required degreasing substances are added in the feeder or in the furnace above the rollers. The degreasing substances used for brick manufacture are either the river or pit sand or the power plant ashes, which are frequently used or wastes or fire roof tiling, in a percentage of $20 \%$.

As the useful loessoid clayey mass consists of layers of various qualities. These are completely processed and homogenized by mixing in the Muller, rollers and mixer to provide the uniformity of the raw materials. The technological flow follows:

- Preparation of materials: proportioning of the components, mixing;

- Cleaning, greasing of pallets;

- Forming: compaction, finishing, tilling $180^{\circ}$;

- Hardening;

- Sorting, storage: piece by piece control, sized, indentations, cracks, quality class, marking, storing.

The products are subjected to drying and transported by cable travel in the Kowo type natural dryers. Firing takes place in a Hoffman furnace with drying temperature at $950^{\circ} \mathrm{C}$ to $1000^{\circ} \mathrm{C}$. 


\section{CONCLUSIONS}

The loessoid clays of the Cobadin deposit situated in the South Dobrogea on the continental plateau of the Black Sea represent one of the most valuable raw materials of this region. The mineralogical, lithological and physico-ceramic characteristics as well as the mining that has been continuously carried out for over 30 years place them among the raw materials most frequently used for the traditional Romanian ceramics.

The physic-ceramic determinations proved that the clays from the Cobadin Plateau have a good capability as raw materials. The clay preparation and working process includes maceration in the quarry, preparation of the material by batching and mixing, shaping, compacting, finishing, hardening. The products are dried in the Kowo type natural dryers of the factory and firing takes place in a Hoffman kiln at a temperature of $950^{\circ} \mathrm{C}$ $-1000^{\circ} \mathrm{C}$.

The products what are obtained by loessoid clays from Cobadin are taken part from the traditional building ceramic: bricks, bricks with holes and ceramic blocks. They represent only $0.6 \%$ of need Romanian market for such products, but cover an important region by decreasing the cost of transport and the cost of re-building of environment after closing, because the protection of environmental is regulated by national and international laws and standards.

\section{REFERENCES}

Ciornei N., Marica S., Cetean V 2002 - Study by long term (2050 year) of the energetical, natural and recycling re sources, base of economic, intra and extrasectorial equilibrium (aggregates, clayey for ceramics, dimension stone)

Marica S., 1993. Geological and technological study for clay reserves from Cobadin deposit, Constantza County, Procema Geological Archive, no 88, Bucharest (in Romanian)

Marica S., 2001. Synthesis study on resources raw materials using in building industry from Constantza County, Procema Geological Archive, Bucharest (in Romanian)

Mutihac V., 1990. Geological Structure of Romanian territory, Technical Publishing House, Bucharest (in Romanian). 